\title{
Physical Activity- and Alcohol-dependent Association Between Air Pollution Exposure and Elevated Liver Enzyme Levels: An Elderly Panel Study
}

\author{
Kyoung-Nam Kim ${ }^{1}$, Hyemi Lee' ${ }^{1}$ Jin Hee Kim², Kweon Jung ${ }^{3}$, Youn-Hee Lim ${ }^{4,5}$, Yun-Chul Hong ${ }^{1,4,5}$ \\ ${ }^{1}$ Department of Preventive Medicine, Seoul National University College of Medicine, Seoul; ${ }^{2}$ Department of Environmental Health, Graduate School \\ of Public Health, Seoul National University, Seoul; ${ }^{3}$ Seoul Metropolitan Institute of Public Health and Environment, Seoul; ${ }^{4}$ Institute of Environmental \\ Medicine, Seoul National University Medical Research Center, Seoul; ${ }^{5}$ Environmental Health Center, Seoul National University College of Medicine, \\ Seoul, Korea
}

Objectives: The deleterious effects of air pollution on various health outcomes have been demonstrated. However, few studies have examined the effects of air pollution on liver enzyme levels.

Methods: Blood samples were drawn up to three times between 2008 and 2010 from 545 elderly individuals who regularly visited a community welfare center in Seoul, Korea. Data regarding ambient air pollutants (particulate matter $\leq 2.5 \mu \mathrm{m}\left[\mathrm{PM}_{2.5}\right]$, nitrogen dioxide $\left[\mathrm{NO}_{2}\right]$, ozone $\left[\mathrm{O}_{3}\right]$, carbon monoxide, and sulfur dioxide) from monitoring stations were used to estimate air pollution exposure. The effects of the air pollutants on the concentrations of three liver enzymes (aspartate aminotransferase [AST], alanine aminotransferase [ALT], and $\gamma$-glutamyltranspeptidase [ $\gamma$-GTP)]) were evaluated using generalized additive and linear mixed models.

Results: Interquartile range increases in the concentrations of the pollutants showed significant associations of PM 2.5 with AST (3.0\% increase, $p=0.0052)$, ALT (3.2\% increase, $p=0.0313)$, and $\gamma$-GTP $(5.0 \%$ increase, $p=0.0051)$ levels; $\mathrm{NO}_{2}$ with AST ( $3.5 \%$ increase, $p=0.0060)$ and ALT ( $3.8 \%$ increase, $p=0.0179)$ levels; and $\mathrm{O}_{3}$ with $\gamma$-GTP $(5.3 \%$ increase, $p=0.0324)$ levels. Significant modification of these effects by exercise and alcohol consumption was found ( $p$ for interaction $<0.05$ ). The effects of air pollutants were greater in non-exercisers and heavy drinkers.

Conclusions: Short-term exposure to air pollutants such as $\mathrm{PM}_{2.5}, \mathrm{NO}_{2}$, and $\mathrm{O}_{3}$ is associated with increased liver enzyme levels in the elderly. These adverse effects can be reduced by exercising regularly and abstinence from alcohol.

Key words: Air pollution, Liver, Nitrogen dioxide, Ozone, Particulate matter

\section{INTRODUCTION}

Received: February 23, 2015 Accepted: April 30, 2015

Corresponding author: Yun-Chul Hong, MD, PhD

103 Daehak-ro, Jongno-gu, Seoul 110-799, Korea

Tel: +82-2-740-8394, Fax: +82-2-747-4830

E-mail: ychong1@snu.ac.kr

This is an Open Access article distributed under the terms of the Creative Commons Attribution Non-Commercial License (http://creativecommons.org/licenses/by$\mathrm{nc} / 3.0 /$ ) which permits unrestricted non-commercial use, distribution, and reproduction in any medium, provided the original work is properly cited.
Air pollution has been associated with increased morbidity and mortality [1-5], insulin resistance [6], systemic inflammation and immune injury [7], and symptoms of depression [8]. Oxidative stress has been suggested as a major pathophysiological mechanism by which air pollutants adversely affect health [5,9-14].

Several studies have associated oxidative stress and systemic inflammation with elevated levels of liver enzymes, includ- 
ing aspartate aminotransferase (AST), alanine aminotransferase (ALT), and $\gamma$-glutamyltranspeptidase ( $\gamma$-GTP) $[15,16]$. This is biochemically plausible because cytochrome P-450 enzymes, which play an important role in producing reactive oxygen species, are abundant in the liver $[17,18]$.

Elevated levels of liver enzymes are independently associated with cardiovascular morbidity, metabolic syndrome, and diabetes mellitus $[16,19]$. However, few studies have addressed the relationship between air pollution and liver enzyme levels, despite its potential clinical importance and biological plausibility; three animal studies have associated air pollution exposure with elevated liver enzyme levels or fatty changes of the liver $[18,20]$, and one cross-sectional study has linked particulate matter $\leq 2.5 \mu \mathrm{m}\left(\mathrm{PM}_{2.5}\right)$ to $\gamma$-GTP levels in humans [21].

Modifiable lifestyle factors, such as regular exercise and alcohol consumption, have been demonstrated to affect individual antioxidant activity and baseline oxidative stress [22,23]. Several studies have reported these effects in liver tissue [22,24-26]. Therefore, it is possible that these lifestyle factors could modulate the effects of air pollution exposure on the liver, which is mediated by oxidative stress.

In the current study, we hypothesized that short-term exposure to air pollutants could induce subclinical liver damage and increase liver enzyme levels. We also investigated whether this effect can be modulated by exercise and alcohol consumption in an elderly population.

\section{METHODS}

\section{Study Population}

The Korean Elderly Environmental Panel study was conducted between 2008 and 2010 to evaluate the association between environmental risk factors and health outcomes in the elderly. A total of 560 participants who regularly visited a community welfare center in the Seongbuk-gu area of Seoul, Korea were recruited. The inclusion criteria for the study were being at least 60 years of age and being able to understand the study. Of the 560 participants, those with unavailable blood samples $(n=12)$ and those with any type of viral hepatitis $(n=2)$ or liver cancer $(n=1)$ were excluded, resulting in a total of 545 participants whose data were analyzed.

Three surveys with blood sampling were performed during the study period, although some subjects did not participate in all three surveys. The first survey was conducted between August 2008 and December 2008, the second survey was con- ducted between April 2009 and September 2009, and the third survey was conducted between March 2010 and August 2010. Detailed information, including demographic characteristics, lifestyle factors, and medical history, was obtained by trained interviewers using a structured questionnaire. All participants submitted written informed consent, and the institutional review board (IRB) of Seoul National University Hospital reviewed and approved the study protocol (IRB no. H-0804-045-241).

\section{Environmental Variables}

Daily concentrations of $\mathrm{PM}_{2.5}$ and gaseous pollutants (nitrogen dioxide $\left[\mathrm{NO}_{2}\right]$, ozone $\left[\mathrm{O}_{3}\right]$, carbon monoxide [CO], and sulfur dioxide $\left[\mathrm{SO}_{2}\right]$ ) were calculated from the 24-hour monitoring data of the Research Institute of Public Health and Environment, Seoul, Korea. The individual exposure of Seongbuk-gu residents to air pollutants was estimated with a monitor located in the center of the Seongbuk-gu area. The individual exposure of residents of other areas was estimated by use of the monitor nearest to their residential address. The average distance between a participant's residence and the nearest monitoring site was $<1 \mathrm{~km}$ (Supplemental Figure 1). Detailed information about the measurement method has been presented elsewhere [8]. Daily average temperatures and dew points measured at the monitoring center nearest each participant's residence were obtained from the Korea Meteorological Administration, Seoul, Korea.

\section{Measurement of Liver Enzyme Concentrations}

Blood samples (up to $3 \mathrm{~mL}$ ) were collected and preserved at $-70^{\circ} \mathrm{C}$ until AST, ALT, and $\gamma$-GTP concentrations were determined via an autobiochemical analyzer (Hitachi 7600-II; Hitachi High-Technologies, Tokyo, Japan) using Pureauto S AST, Pureauto S ALT, and Pureauto S Y-GTP (Daiichi Pure Chemicals, Tokyo, Japan) as reagents.

\section{Statistical Analysis}

As the distributions of the three liver enzymes were rightskewed, their concentrations were natural log-transformed to approximate a normal distribution. Liver enzyme levels were measured up to three times for each participant. Since the observations for each participant were correlated, we assessed the effects of an interquartile range (IQR) increase of the concentration of each pollutant on AST, ALT, and $\gamma$-GTP levels using linear mixed models with random effects for each participant. The linearity of the association was assessed using generalized addi- 
tive mixed models. Delayed effects of air pollutants on liver enzymes were assessed by applying lag structures up to six days before each survey visit. In the single-day lag model, lag 0 corresponds to the pollutant concentration measured on the day of the visit and lag 6 corresponds to the pollutant concentration measured six days prior to the day of the visit. After the effects of each pollutant were evaluated individually, a multiple-pollutant model based on the air pollutants that were significantly associated with liver enzyme levels was constructed to assess the robustness of the pollutants' effects. All models were adjusted for potential confounders selected a priori, including age, sex, smoking status (information not available, smoker, ex-smoker, or non-smoker), mean temperature, dew point, season (March, April, May; June, July, August; September, October, November; or December, January, February), body mass index (BMl; weight [in kilograms]/height [in meters squared]), alcohol consumption (information not available, no, less than once a week, or once a week or more), and whether subjects engaged in moderate physical activity at least once a week (information not available, no, yes). Mean temperature, dew point, and season were included in the models as time-varying variables, while other covariates such as age, sex, smoking status, BMI, alcohol consumption, and physical activity status were included as time-independent variables.

A multiplicative interaction term between each air pollutant and covariate was added to the main model sequentially, and the significance of each interaction term $(p<0.05)$ was assessed by the log likelihood ratio test. Stratified analyses were conducted for each covariate that showed significant interaction.

Several sensitivity analyses were performed. First, the delayed and cumulative effects of air pollutants on liver enzyme levels were explored using multi-day lag models and unconstrained distributed lag models, respectively. In multi-day lag models, lag 01 , which corresponds to the moving average of pollutant concentrations measured on the day of the visit and the previous day, to lag 06 , which corresponds to the moving average of pollutant concentrations measured on the day of the visit and the previous 6 days, were applied. In unconstrained distributed lag models, the cumulative effects of air pollutants over singleday lag periods were estimated and lag 0 to 1 , which refers to lag 0 and lag 1 in the model, to lag 0 to 6 , which refers to lag 0 through lag 6 in the model, were applied. Second, the association between air pollutants and liver enzyme levels was evaluated after restricting the analyses to the participants who reported that they did not drink alcohol. Third, all analyses were performed once more after weighing the follow-up observations by the inverse probability of having a follow-up response [27], because selection bias can occur if the loss to follow-up is not random. The predicted probability of follow-up was estimated by logistic regression with covariates including age, sex $\mathrm{BMI}$, number of years of schooling, blood pressure, season, and outdoor temperature at the prior visit. A weight of 1 was given to the first observation, and more weight was given to followup observations that were more likely to be missing.

All analyses were performed using SAS version 9.4 (SAS Institute Inc., Cary, NC, USA) and R version 3.1.0 (Comprehensive $R$ Archive Network [http://cran.r-project.org]). An alpha level $<0.05$ was defined as indicating statistical significance.

\section{RESULTS}

Of the 545 participants, $73.9 \%$ were females, and the average age was 70.6 years. Among the participants, $85.5 \%$ had not Table 1. Baseline characteristics of the study participants ${ }^{1}$

\begin{tabular}{lc}
\hline Variable & Total (n = 545) \\
\hline Sex & $142(26.1)$ \\
Male & $403(73.9)$ \\
Female & \\
Age $(y)$ & $243(44.6)$ \\
$<70$ & $279(51.2)$ \\
$70-79$ & $23(4.2)$ \\
$\geq 80$ & \\
Smoking & $466(85.5)$ \\
Never & $35(6.4)$ \\
Past & $30(5.5)$ \\
Current & $14(2.6)$ \\
Did not answer & \\
Alcohol consumption & $408(74.9)$ \\
No & $55(10.1)$ \\
$<1 /$ wk & $65(11.9)$ \\
$\geq 1 /$ wk & $17(3.1)$ \\
Did not answer & \\
Exercise & $197(36.2)$ \\
No & $334(61.3)$ \\
Yes & $14(2.6)$ \\
Did not answer & \\
Body mass index $\left(\mathrm{kg} / \mathrm{m}^{2}\right)$ & $241(44.2)$ \\
$<23$ & \\
$23-24.9$ & \\
$\geq 25$ & \\
\hline & \\
\hline
\end{tabular}

Values are presented as number (\%).

'Moderate physical activity at least once a week. 
smoked before, $22.0 \%$ drank alcohol, and $61.3 \%$ exercised moderately at least once a week (Table 1). The average BMI of the study participants was $24.8 \mathrm{~kg} / \mathrm{m}^{2}$.

The mean $\mathrm{PM}_{2.5}, \mathrm{NO}_{2}$, and $\mathrm{SO}_{2}$ concentrations during the study periods (August 2008 to December 2008, April 2009 to September 2009, and March 2010 to August 2010) were 23.2 $\mu \mathrm{g} / \mathrm{m}^{3}, 36.2 \mathrm{ppb}$, and $3.9 \mathrm{ppb}$, respectively. The maximum concentrations of $\mathrm{O}_{3}$ and $\mathrm{CO}$ were 47.7 and $0.8 \mathrm{ppm}$, respectively. The mean temperature \pm standard deviation was $17.4^{\circ} \mathrm{C} \pm$ $8.1^{\circ} \mathrm{C}$, and the dew point was $6.4^{\circ} \mathrm{C} \pm 9.5^{\circ} \mathrm{C}$ (Supplemental Table 1, Supplemental Figure 2). The levels of the pollutants were highly correlated with each other, except for $\mathrm{O}_{3}$ (Supplemental Table 2).

We examined the association between air pollutants and liver enzyme levels using single-day lag models (Table 2). IQR increases in $\mathrm{PM}_{2.5}$ concentrations were significantly associated with elevated AST (strongest association in lag 3; 3.0\% increase; 95\% confidence interval [Cl], 0.9 to 5.1\%), ALT (lag 2; 3.2\% increase; $95 \% \mathrm{Cl}, 0.3$ to $6.2 \%)$, and $\mathrm{Y}$-GTP (lag 3; $5.0 \%$ increase;
$95 \% \mathrm{Cl}, 1.5$ to $8.7 \%$ ) levels. IQR increases in $\mathrm{NO}_{2}$ concentrations were associated with elevated AST (lag 2; 3.5\% increase; 95\% $\mathrm{Cl}, 1.0$ to $6.1 \%$ ) and ALT (lag 2; $3.8 \%$ increase; $95 \% \mathrm{Cl}, 0.6$ to 7.0\%) levels. IQR increases in $\mathrm{O}_{3}$ concentrations were associated with elevations in $\gamma$-GTP levels (lag 4; 5.3\% increase; $95 \% \mathrm{Cl}, 0.4$ to $10.4 \%)$. The observed association between air pollutants and liver enzymes was almost linear in a generalized additive mixed model (Figure 1).

The multiple-pollutant models constructed for $\mathrm{PM}_{2.5}, \mathrm{NO}_{2}$, and $\mathrm{O}_{3}$ showed a significant association of $\mathrm{\gamma}$-GTP levels with IQR increases in $\mathrm{PM}_{2.5}$ concentrations $(4.3 \%$ increase; $95 \% \mathrm{Cl}, 0.5$ to $8.3 \%$ ) when adjusted for $\mathrm{NO}_{2}$ and $\mathrm{O}_{3}$ concentrations. Marginally significant associations of AST levels with $\mathrm{PM}_{2.5}$ concentrations $(2.1 \%$ increase; $95 \% \mathrm{Cl},-0.1$ to $-4.5 \%)$ and $\mathrm{NO}_{2}$ concentrations (2.5\% increase; $95 \% \mathrm{Cl},-0.1$ to $-5.3 \%)$ were also observed (Table 3).

When the interaction term between each air pollutant and covariate was added to the main model, the only significant interactions observed were the interactions of $\mathrm{PM}_{2.5}$ with physical

Table 2. Percent change in liver enzyme levels with an interquartile range increase in the concentrations of air pollutants in single-day lag models

\begin{tabular}{|c|c|c|c|c|c|c|c|c|c|c|}
\hline \multirow{2}{*}{ IQR } & & \multicolumn{3}{|c|}{ AST } & \multicolumn{3}{|c|}{ ALT } & \multicolumn{3}{|c|}{$\gamma$-GTP } \\
\hline & & Estimate & $95 \% \mathrm{Cl}$ & p-value & Estimate & $95 \% \mathrm{Cl}$ & p-value & Estimate & $95 \% \mathrm{Cl}$ & p-value \\
\hline \multicolumn{11}{|c|}{ Model 1 (adjusted for age, sex, smoking, amount of exercise, mean temperature, dew point, and season) } \\
\hline $\mathrm{PM}_{2.5}$ & $13.2 \mu \mathrm{g} / \mathrm{m}^{3}$ & 2.9 & $0.8,5.0$ & 0.006 & 2.7 & $-0.2,5.8$ & 0.07 & 4.8 & $1.2,8.6$ & 0.008 \\
\hline $\mathrm{NO}_{2}$ & $14.4 \mathrm{ppb}$ & 3.2 & $0.7,7.3$ & 0.01 & 3.3 & $0.2,6.6$ & 0.04 & -2.6 & $-6.5,1.5$ & 0.21 \\
\hline $\mathrm{O}_{3}$ & $38.5 \mathrm{ppb}$ & 1.5 & $-1.8,4.8$ & 0.38 & 3.0 & $-0.7,6.8$ & 0.11 & 5.6 & $0.6,10.9$ & 0.03 \\
\hline $\mathrm{CO}$ & 4.0 ppm & 0.9 & $-1.2,3.1$ & 0.41 & 2.5 & $-0.3,5.3$ & 0.08 & -1.9 & $-5.8,2.1$ & 0.35 \\
\hline $\mathrm{SO}_{2}$ & $2.3 \mathrm{ppb}$ & 1.6 & $-0.8,4.1$ & 0.19 & -1.9 & $-4.9,1.2$ & 0.23 & -2.8 & $-6.8,1.3$ & 0.18 \\
\hline \multicolumn{11}{|c|}{ Model 2 (adjusted as in Model 1 plus BMI) } \\
\hline $\mathrm{PM}_{2.5}$ & $13.2 \mu \mathrm{g} / \mathrm{m}^{3}$ & 2.9 & $0.9,5.1$ & 0.005 & 3.2 & $0.3,6.2$ & 0.03 & 4.9 & $1.4,8.6$ & 0.007 \\
\hline $\mathrm{NO}_{2}$ & 14.4 ppb & 3.5 & $1.0,6.0$ & 0.007 & 3.7 & $0.6,6.9$ & 0.02 & -2.6 & $-6.5,1.4$ & 0.20 \\
\hline $\mathrm{O}_{3}$ & 38.5 ppb & 1.8 & $-1.5,5.1$ & 0.29 & 2.5 & $-1.1,6.2$ & 0.17 & 5.4 & $0.5,10.6$ & 0.03 \\
\hline CO & 4.0 ppm & 0.9 & $-1.2,3.1$ & 0.40 & 2.5 & $-0.2,5.3$ & 0.07 & -2.0 & $-5.9,1.9$ & 0.31 \\
\hline $\mathrm{SO}_{2}$ & $2.3 \mathrm{ppb}$ & 1.8 & $-0.6,4.3$ & 0.15 & -1.8 & $-4.7,1.3$ & 0.25 & -2.7 & $-6.6,1.4$ & 0.19 \\
\hline \multicolumn{11}{|c|}{ Model 3 (adjusted as in Model 1 plus BMI and alcohol consumption) } \\
\hline $\mathrm{PM}_{2.5}$ & $13.2 \mu \mathrm{g} / \mathrm{m}^{3}$ & 3.0 & $0.9,5.1$ & 0.005 & 3.2 & $0.3,6.2$ & 0.03 & 5.0 & $1.5,8.7$ & 0.005 \\
\hline $\mathrm{NO}_{2}$ & $14.4 \mathrm{ppb}$ & 3.5 & $1.0,6.1$ & 0.006 & 3.8 & $0.6,7.0$ & 0.02 & -2.7 & $-6.5,1.3$ & 0.18 \\
\hline $\mathrm{O}_{3}$ & $38.5 \mathrm{ppb}$ & 1.7 & $-1.5,5.1$ & 0.29 & 2.6 & $-1.0,6.3$ & 0.16 & 5.3 & $0.4,10.4$ & 0.03 \\
\hline CO & 4.0 ppm & 1.0 & $-1.1,3.2$ & 0.36 & 2.6 & $-0.2,5.4$ & 0.06 & -1.9 & $-5.6,2.1$ & 0.35 \\
\hline $\mathrm{SO}_{2}$ & $2.3 \mathrm{ppb}$ & 1.8 & $-0.7,4.3$ & 0.15 & -1.8 & $-4.8,1.2$ & 0.24 & -2.7 & $-6.7,1.3$ & 0.18 \\
\hline
\end{tabular}

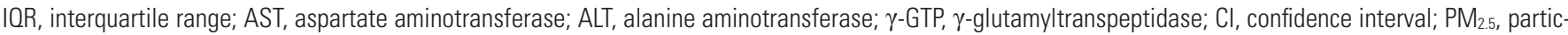
ulate matter $\leq 2.5 \mu \mathrm{m} ; \mathrm{NO}_{2}$, nitrogen dioxide; $\mathrm{O}_{3}$, ozone; $\mathrm{CO}$, carbon monoxide; $\mathrm{SO}_{2}$, sulfur dioxide; ppb, parts per billion; ppm, parts per million; $\mathrm{BMI}$, body mass index.

${ }^{1}$ Associations with AST are shown for $\mathrm{NO}_{2}, \mathrm{O}_{3}$, and $\mathrm{CO}$ on lag day 2 and for $\mathrm{PM}_{2.5}$ and $\mathrm{SO}_{2}$ on lag day 3 . Associations with $\mathrm{ALT}$ are shown for $\mathrm{SO}_{2}$ on lag day 1 ; for $\mathrm{PM}_{2.5}, \mathrm{NO}_{2}$, and $\mathrm{CO}$ on lag day 2; and for $\mathrm{O}_{3}$ on lag day 5. Associations with $\gamma$-GTP are shown for $\mathrm{NO}_{2}$ and $\mathrm{SO}_{2}$ on lag day 1 , for $\mathrm{PM}_{2.5}$ on lag day 3 , and for $\mathrm{O}_{3}$ and $\mathrm{CO}$ on lag day 4 . 
activity on AST levels $(p=0.0388)$ and of alcohol consumption on $\gamma$-GTP levels $(p=0.0082)$. When stratified by the covariates showing significant interaction with air pollutants, such as physical activity and alcohol consumption status, the effect size of $\mathrm{PM}_{2.5}$ on AST levels was larger in participants who did not engage in moderate physical activity at least once a week $(5.4 \%$ increase; $95 \% \mathrm{Cl}, 2.3$ to $8.5 \%)$ than in those who did $(0.6 \%$ increase; $95 \% \mathrm{Cl},-2.1$ to $3.4 \%$ ). Likewise, the effect size of $\mathrm{PM}_{2.5}$ on $\mathrm{\gamma}$-GTP levels was larger in participants who drank at least once a week (20.1\% increase; $95 \% \mathrm{Cl}, 6.3$ to $33.8 \%$ ) than in non-drinkers ( $2.8 \%$ increase; $95 \% \mathrm{Cl},-0.8$ to $6.4 \%$ ) (Figure 2, Supplemental Table 3).

The sensitivity of the results was tested in several ways. First, different lag structures were applied to assess the delayed and cumulative effect of air pollutants on liver enzyme levels. In both multi-day lag models (Supplemental Figure 3, Supplemen-
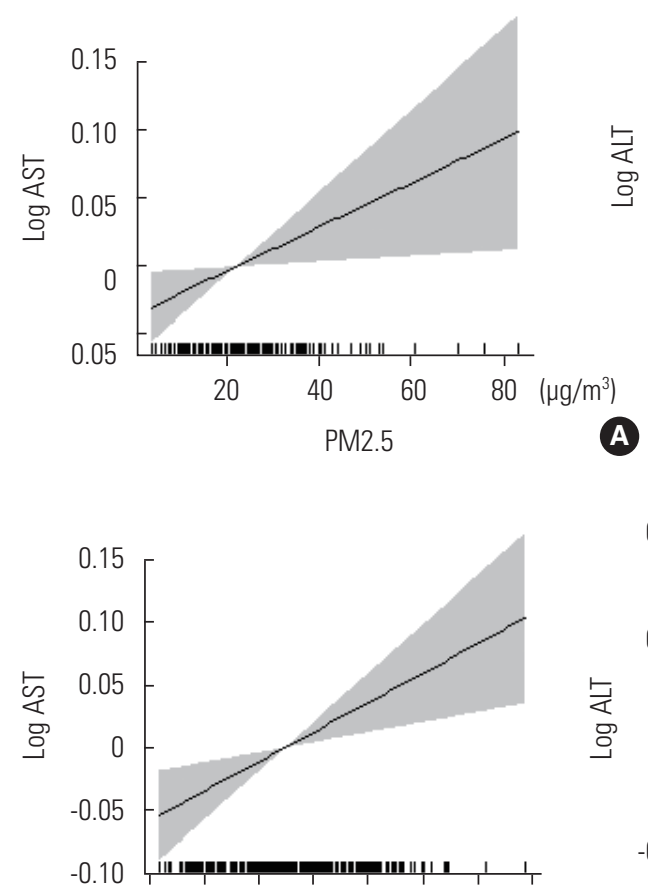

0.010 .020 .030 .040 .050 .060070 .08 (ppb)

$\mathrm{NO}_{2}$

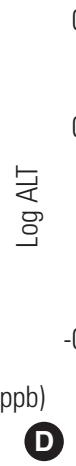

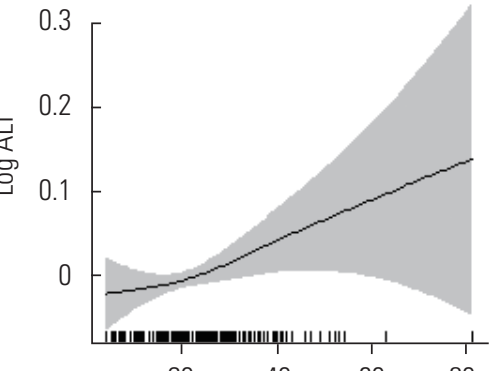

20
PM2.5

.20

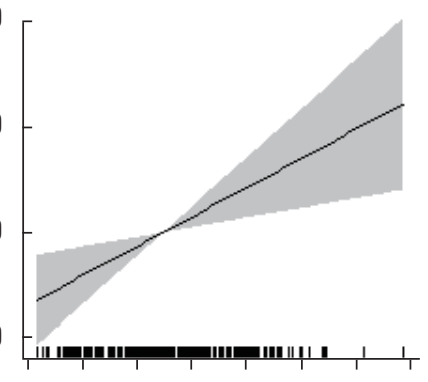

$0.010 .020 .030 .040 .050 .060070 .08(p p b)$

$\mathrm{NO}_{2}$
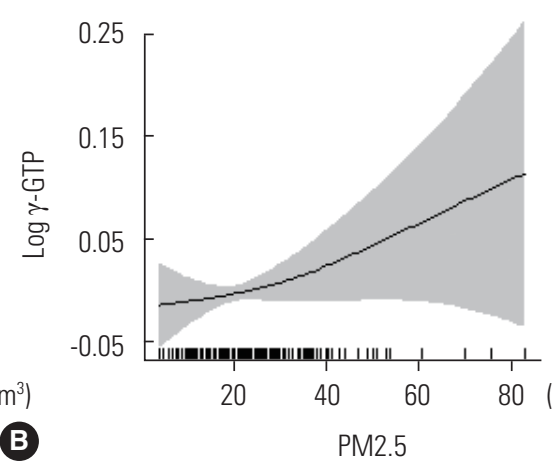

20 PM2.5 $\left(\mu \mathrm{g} / \mathrm{m}^{3}\right.$

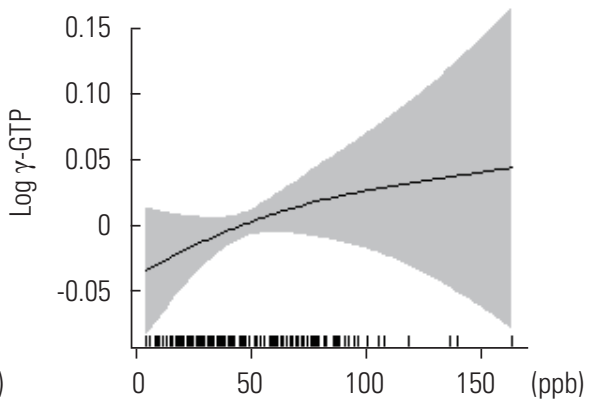

E

Figure 1. Penalized regression splines of particulate matter $\leq 2.5 \mu \mathrm{m}\left(\mathrm{PM}_{2.5}\right)$ concentrations on (A) lag day 3 for aspartate aminotransferase (AST), (B) lag day 2 for alanine aminotransferase (ALT), and (C) lag day 3 for $\gamma$-glutamyltranspeptidase ( $\gamma$-GTP); nitrogen dioxide $\left(\mathrm{NO}_{2}\right)$ concentrations on (D) lag day 2 for AST and (E) ALT; and ozone $\left(\mathrm{O}_{3}\right)$ concentrations on (F) lag day 4 for $\gamma$-GTP. Solid lines, spline curve; shaded area, 95\% confidence interval. Y-axis indicates difference from the mean of each log-transformed liver enzyme level. All models were adjusted for age, sex, smoking status, mean temperature, dew point, season, body mass index, alcohol consumption, and amount of exercise. ppb, parts per billion.

Table 3. Percent change in liver enzyme concentrations with interquartile range increases in $\mathrm{PM}_{2.5}, \mathrm{NO}_{2}$, and $\mathrm{O}_{3}$ concentrations in multiple-pollutant models ${ }^{1}$

\begin{tabular}{|c|c|c|c|c|c|c|c|c|c|c|}
\hline \multirow{2}{*}{ IQR } & & \multicolumn{3}{|c|}{ AST } & \multicolumn{3}{|c|}{ ALT } & \multicolumn{3}{|c|}{$\gamma$-GTP } \\
\hline & & Estimate & $95 \% \mathrm{Cl}$ & $p$-value & Estimate & $95 \% \mathrm{CI}$ & $p$-value & Estimate & $95 \% \mathrm{Cl}$ & $p$-value \\
\hline $\mathrm{PM}_{2.5}$ & $13.2 \mu \mathrm{g} / \mathrm{m}^{3}$ & 2.1 & $-0.1,4.5$ & 0.07 & 1.2 & $-2.6,5.0$ & 0.55 & 4.3 & $0.5,8.3$ & 0.03 \\
\hline $\mathrm{NO}_{2}$ & $14.4 \mathrm{ppb}$ & 2.5 & $-0.1,5.3$ & 0.06 & 3.1 & $-1.0,7.3$ & 0.14 & -2.7 & $-6.6,1.4$ & 0.20 \\
\hline $\mathrm{O}_{3}$ & $38.5 \mathrm{ppb}$ & 0.5 & $-2.8,3.9$ & 0.77 & 2.9 & $-0.8,6.7$ & 0.12 & 2.5 & $-2.9,8.2$ & 0.37 \\
\hline
\end{tabular}

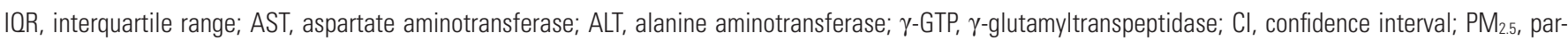
ticulate matter $\leq 2.5 \mu \mathrm{m} ; \mathrm{NO}_{2}$, nitrogen dioxide; $\mathrm{O}_{3}$, ozone; ppb, parts per billion.

${ }^{1}$ Models for AST were constructed using the values for $\mathrm{NO}_{2}$ and $\mathrm{O}_{3}$ on lag day 2 and $\mathrm{PM}_{2.5}$ on lag day 3. Models for ALT were constructed using the values for $\mathrm{NO}_{2}$ and $\mathrm{PM}_{2.5}$ on lag day 2 and $\mathrm{O}_{3}$ on lag day 5. Models for $\gamma$-GTP were constructed using the values for $\mathrm{NO}_{2}$ on day $1, \mathrm{PM}_{2.5}$ on day 3 , and $\mathrm{O}_{3}$ on day 4 . All models were adjusted for age, sex, smoking status, mean temperature, dew point, season, body mass index, alcohol consumption, and amount of exercise. 
$\mathrm{PM}_{2.5}$

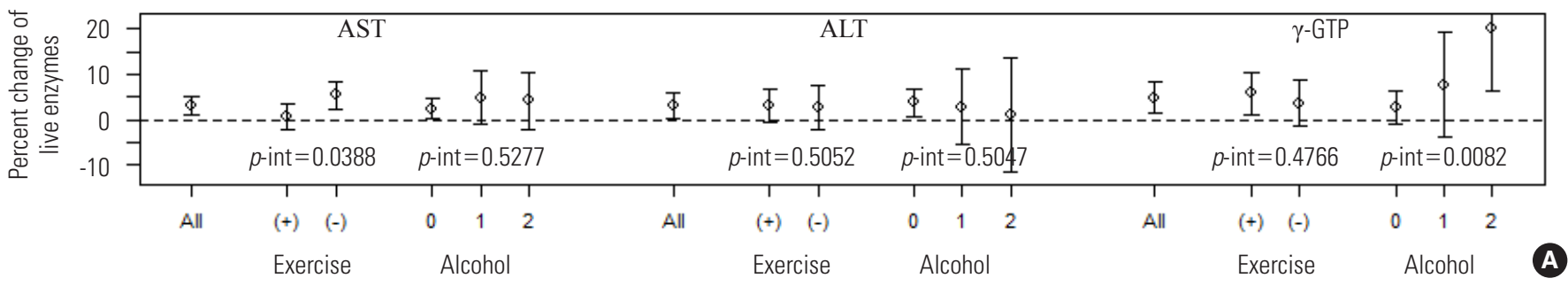

$\mathrm{NO}_{2}$

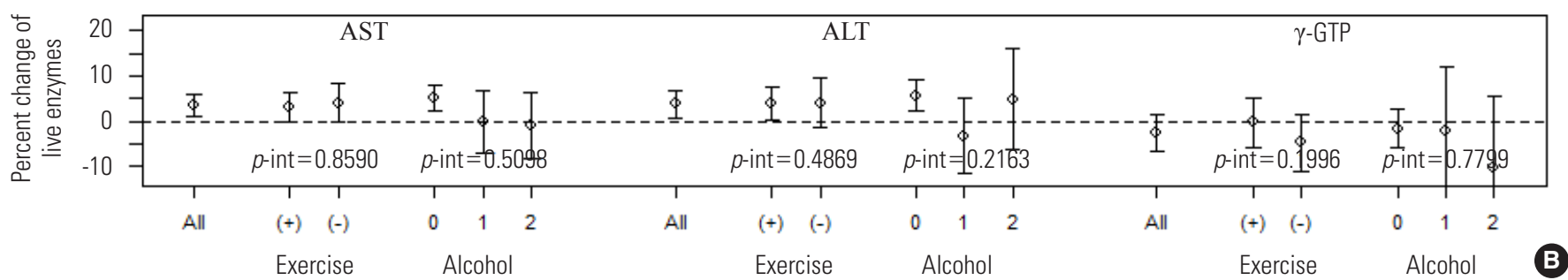

$\mathrm{O}_{3}$

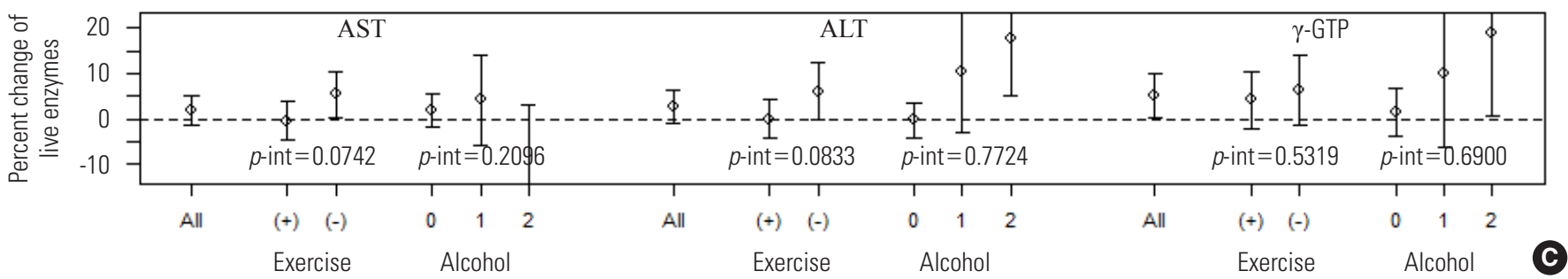

Figure 2. The percent change in aspartate aminotransferase (AST), alanine aminotransferase (ALT), Y-glutamyltranspeptidase $(\gamma$-GTP) levels with an interquartile range increase in the concentrations of $(A)$ particulate matter $\leq 2.5 \mu m$, (B) nitrogen dioxide, and (C) ozone, stratified by physical activity and alcohol drinking. Exercise (+), moderate physical activity at least once a week; Exercise (-), moderate physical activity less than once a week; Alcohol 0, non-drinker; Alcohol 1, alcohol drinking less than once a week; Alcohol 2, alcohol drinking at least once a week; $p$-int, $p$-value for interaction.

tal Table 4) and distributed lag models (Supplemental Figure 4, Supplemental Table 5), the results were robust. Second, we assessed the association between short-term air pollution exposure and liver enzyme levels after restricting the analyses to non-drinkers $(n=408)$, who were more likely to be female (85.3\% for non-drinkers vs. 35.8\% for drinkers) but had almost the same age distribution as drinkers (mean age of 71 years for non-drinkers vs. 70 years for drinkers). Among the non-drinkers, IQR increases in $\mathrm{PM}_{2.5}$ concentrations were associated with elevated AST (lag 3; 2.5\% increase; $95 \% \mathrm{Cl}, 0.1$ to 5.0\%) and ALT (lag 2; 3.8\% increase; $95 \% \mathrm{Cl}, 0.5$ to $7.2 \%$ ) levels, and IQR increases in $\mathrm{NO}_{2}$ concentrations were associated with elevated AST (lag 2; 5.1\% increase; 95\% Cl, 2.1 to 8.1\%) and ALT (lag 2; $5.8 \%$ increase; $95 \% \mathrm{Cl}, 2.2$ to $9.5 \%$ ) levels, showing almost identical results, although some associations were attenuated due to the small sample size. Third, after the follow-up observations were weighted by the inverse probability of attaining a follow-up response, substantial changes were not observed (Supplemental Table 6).

\section{DISCUSSION}

We found that liver enzyme levels were significantly associated with exposure to $\mathrm{PM}_{2.5}$ (AST, ALT, $\mathrm{Y}$-GTP), $\mathrm{NO}_{2}$ (AST and $\mathrm{ALT})$, and $\mathrm{O}_{3}(\gamma-\mathrm{GTP})$ concentrations. Multiple-pollutant models incorporating $\mathrm{PM}_{2.5}, \mathrm{NO}_{2}$, and $\mathrm{O}_{3}$, showed a significant association between $\mathrm{PM}_{2.5}$ and $\mathrm{Y}$-GTP concentrations when adjusted for $\mathrm{NO}_{2}$ and $\mathrm{O}_{3}$ concentrations. However, the effect of air pollution on the liver can be reduced by modifiable lifestyle factors, such as regular exercise or less frequent consumption 
of alcohol.

In the present study, only the oxidant-producing pollutants, $\mathrm{PM}_{2.5}, \mathrm{NO}_{2}$, and $\mathrm{O}_{3}$, showed a significant association with elevated liver enzyme levels. Inflammation in the respiratory tract, triggered by oxidative stress induced by these pollutants, can lead to subsequent systemic inflammation and affect various peripheral organs, including the liver. Previous studies have reported that short-term exposure to oxidant-producing pollutants such as $\mathrm{PM}_{10}, \mathrm{NO}_{2}$, and $\mathrm{O}_{3}$ increased symptoms of depression [8] and insulin resistance [6]. Our findings are in line with these reports and support the premise that oxidative stress mediates the toxic effects of air pollutants $[14,28]$.

Elevated levels of liver enzymes, including AST, ALT, and $\mathrm{p}$-GTP, have been reported to independently predict cardiovascular disease [29-31], metabolic syndrome [32,33], and diabetes mellitus $[34,35]$. These findings and ours suggest that the associations between air pollution and these conditions may be explained, at least in part, by common oxidative stress pathways. Since the current study only investigated the short-term effects of air pollution, future studies should focus on the long-term effects of air pollution on liver function and the biological pathways connecting air pollution, liver enzymes, and various adverse health outcomes.

In multiple-pollutant models based on the three pollutants associated with liver enzyme levels in single-pollutant models $\left(\mathrm{PM}_{2.5}, \mathrm{NO}_{2}\right.$, and $\left.\mathrm{O}_{3}\right)$, only the significant association between $\mathrm{PM}_{2.5}$ and $\gamma$-GTP remained robust. This finding is consistent with a previous cross-sectional study showing a significant relationship between $\mathrm{PM}_{2.5}$ and $\mathrm{\gamma}$-GTP [21]. Multiple-pollutant models also showed a statistical trend for associations of $\mathrm{PM}_{2.5}$ and $\mathrm{NO}_{2}$ with $\mathrm{AST}$, as observed in the present study. Differences between the effects estimated from single-pollutant and multiple-pollutant models are commonly observed in air pollution studies [36]. The model-related discrepancies observed in the present study might reflect the high correlation of air pollutant levels or insufficient statistical power due to the relatively small sample size $(n=545)$. Studies with larger sample sizes are needed to evaluate the independent effects of $\mathrm{PM}_{2.5}, \mathrm{NO}_{2}$, and $\mathrm{O}_{3}$ on liver enzyme levels.

The effect of air pollution on liver enzyme levels was smaller in participants who engaged in moderate physical activity at least once a week or consumed alcohol less than once a week or not at all. Regular exercise has been reported to decrease reactive oxygen species and oxidative stress in rat livers [24]. The increase in antioxidant activity and damage repair enzymes, caused by exercise in conjunction with an associated lower baseline of reactive oxygen species, is thought to occur through an adaptive process $[37,38]$ although the protective effects of regular exercise could be cancelled out by the increased exposure to air pollution, especially in highly polluted areas. Previous studies have also demonstrated that acute or chronic alcohol exposure can induce oxidative stress, which plays a major role in producing hepatocyte toxicity due to alcohol $[23,25,26,39]$. Each participant's physical activity or alcohol consumption status affects individual rates of reactive oxygen species formation and antioxidant activity levels, thereby modifying the association between exposure to air pollutants and liver enzymes. The findings of the present study suggest strategies for preventing adverse health effects caused by air pollution, which have rarely been investigated.

Air pollutants such as $\mathrm{PM}_{2.5}, \mathrm{NO}_{2}$, and $\mathrm{O}_{3}$ cause oxidative stress through direct and indirect pathways [13]. Exposure to oxidant-producing pollutants that exceeds the antioxidant protective capacity of cells could cause inflammatory processes in the respiratory tract. This could lead to systemic inflammation and circulating inflammatory mediators, which in turn induce the additional generation of reactive oxygen species in peripheral tissue such as the liver [28]. In addition, $\mathrm{PM}_{2.5}$ can penetrate deeply into the alveoli, entering the pulmonary system and presumably the systemic circulation [7], which could be another pathway to reach the liver and induce liver damage. The liver, which is the primary location of cytochrome P-450 enzymes, which are the primary generators of reactive oxygen species, might be vulnerable to these insults $[17,18]$, and an association of oxidative stress and systemic inflammation with elevated levels of liver enzymes has been reported $[15,16]$. Although these findings suggest a potential relationship between air pollution and liver damage, relatively few studies address the mechanisms underlying the relationship between air pollution and liver enzyme levels $[18,20]$. Further studies dealing with biological mechanisms are warranted, as well as epidemiological studies.

Although several models in the present study showed a robust association between air pollution and elevated liver enzyme levels, several limitations should be noted. First, because the current study was conducted on individuals aged $\geq 60$ years, the results might not be generalizable to younger people; it is possible that age modulates the effects of air pollution on liver enzyme levels. Second, we could not control for alcohol consumption over the period immediately preceding the study 
visit because this information was not collected. However, it is unlikely that daily changes in the concentration of air pollutants correlated with the daily alcohol consumption levels of each participant, and restricting the analyses to nondrinkers did not change the results appreciably. Third, the air pollution exposure of each participant was not measured directly, but estimated on the basis of monitoring data nearest to the residence of each participant. However, this methodology for estimating air pollution exposure seems reasonable because most of the study participants were retired or unemployed, and therefore, presumably spent most of their time at or near their homes.

In conclusion, short-term exposure to the air pollutants $\mathrm{PM}_{2.5}$ $\mathrm{NO}_{2}$, and $\mathrm{O}_{3}$ was significantly associated with elevated liver enzyme levels in an elderly population. However, this association was attenuated in participants who engaged in more physical activity or consumed less alcohol. Since a very large population is exposed to air pollution on a daily basis, the results of the present study are potentially important for public health despite the relatively small effect size. Close monitoring and continuous efforts to reduce air pollution level should be conducted.

\section{ACKNOWLEDGEMENTS}

We thank all the study participants, research workers, and technicians who contributed to this study. This research was supported by the R\&D Program and the Women Scientist Research Program for Society of the National Research Foundation funded by the Ministry of Science, ICT \& Future Planning (grant no. 2014M3C8A5030619, 2012 R1A1A3005549).

\section{CONFLICT OF INTEREST}

The authors have no conflicts of interest with the material presented in this paper.

\section{REFERENCES}

1. Burnett RT, Stieb D, Brook JR, Cakmak S, Dales R, Raizenne M, et al. Associations between short-term changes in nitrogen dioxide and mortality in Canadian cities. Arch Environ Health 2004;59(5):228-236.

2. de Kok TM, Driece HA, Hogervorst JG, Briedé JJ. Toxicological assessment of ambient and traffic-related particulate matter: a review of recent studies. Mutat Res 2006;613(2-3):103-122.

3. Hong YC, Lee JT, Kim H, Kwon HJ. Air pollution: a new risk fac- tor in ischemic stroke mortality. Stroke 2002;33(9):2165-2169.

4. Maynard D, Coull BA, Gryparis A, Schwartz J. Mortality risk associated with short-term exposure to traffic particles and sulfates. Environ Health Perspect 2007;115(5):751-755.

5. Pope CA 3rd, Dockery DW. Health effects of fine particulate air pollution: lines that connect. J Air Waste Manag Assoc 2006; 56(6):709-742.

6. Kim JH, Hong YC. GSTM1, GSTT1, and GSTP1 polymorphisms and associations between air pollutants and markers of insulin resistance in elderly Koreans. Environ Health Perspect 2012; 120(10):1378-1384.

7. Zhao J, Gao Z, Tian Z, Xie Y, Xin F, Jiang R, et al. The biological effects of individual-level PM(2.5) exposure on systemic immunity and inflammatory response in traffic policemen. Occup Environ Med 2013;70(6):426-431.

8. Lim YH, Kim H, Kim JH, Bae S, Park HY, Hong YC. Air pollution and symptoms of depression in elderly adults. Environ Health Perspect 2012;120(7):1023-1028.

9. Kelly FJ. Oxidative stress: its role in air pollution and adverse health effects. Occup Environ Med 2003;60(8):612-616.

10. Kim JH, Choi YH, Bae S, Park HY, Hong YC. eNOS gene polymorphisms modify the association of PM(10) with oxidative stress. Toxicol Lett 2012;214(3):263-267.

11. Møller P, Folkmann JK, Forchhammer L, Bräuner EV, Danielsen $\mathrm{PH}$, Risom L, et al. Air pollution, oxidative damage to DNA, and carcinogenesis. Cancer Lett 2008;266(1):84-97.

12. Nel A. Atmosphere. Air pollution-related illness: effects of particles. Science 2005;308(5723):804-806.

13. Romieu I, Moreno-Macias H, London SJ. Gene by environment interaction and ambient air pollution. Proc Am Thorac Soc 2010; 7(2):116-122.

14. Rossner P Jr, Svecova V, Milcova A, Lnenickova Z, Solansky I, Sram RJ. Seasonal variability of oxidative stress markers in city bus drivers. Part I. Oxidative damage to DNA. Mutat Res 2008; 642(1-2):14-20.

15. Yamada J, Tomiyama H, Yambe M, Koji Y, Motobe K, Shiina K, et al. Elevated serum levels of alanine aminotransferase and gamma glutamyltransferase are markers of inflammation and oxidative stress independent of the metabolic syndrome. Atherosclerosis 2006;189(1):198-205.

16. Lioudaki E, Ganotakis ES, Mikhailidis DP. Liver enzymes: potential cardiovascular risk markers? Curr Pharm Des 2011;17(33): 3632-3643.

17. Rösen P, Nawroth PP, King G, Möller W, Tritschler HJ, Packer L. The role of oxidative stress in the onset and progression of di- 
abetes and its complications: a summary of a Congress Series sponsored by UNESCO-MCBN, the American Diabetes Association and the German Diabetes Society. Diabetes Metab Res Rev 2001;17(3):189-212.

18. Tomaru M, Takano H, Inoue K, Yanagisawa R, Osakabe N, Yasuda $A$, et al. Pulmonary exposure to diesel exhaust particles enhances fatty change of the liver in obese diabetic mice. Int J Mol Med 2007;19(1):17-22.

19. Targher G. Elevated serum gamma-glutamyltransferase activity is associated with increased risk of mortality, incident type 2 diabetes, cardiovascular events, chronic kidney disease and cancer-a narrative review. Clin Chem Lab Med 2010;48(2): 147-157.

20. Tan HH, Fiel MI, Sun Q, Guo J, Gordon RE, Chen LC, et al. Kupffer cell activation by ambient air particulate matter exposure may exacerbate non-alcoholic fatty liver disease. J Immunotoxicol 2009;6(4):266-275.

21. Markevych I, Wolf K, Hampel R, Breitner S, Schneider A, von Klot S, et al. Air pollution and liver enzymes. Epidemiology 2013; 24(6):934-935.

22. Radak Z, Chung HY, Goto S. Exercise and hormesis: oxidative stress-related adaptation for successful aging. Biogerontology 2005;6(1):71-75.

23. Sid B, Verrax J, Calderon PB. Role of oxidative stress in the pathogenesis of alcohol-induced liver disease. Free Radic Res 2013;47(11):894-904

24. Radák Z, Chung HY, Naito H, Takahashi R, Jung KJ, Kim HJ, et al. Age-associated increase in oxidative stress and nuclear factor kappaB activation are attenuated in rat liver by regular exercise. FASEB J 2004;18(6):749-750.

25. Kessova IG, Ho YS, Thung S, Cederbaum Al. Alcohol-induced liver injury in mice lacking $\mathrm{Cu}, \mathrm{Zn}$-superoxide dismutase. Hepatology 2003;38(5):1136-1145.

26. Cederbaum Al, Lu Y, Wu D. Role of oxidative stress in alcoholinduced liver injury. Arch Toxicol 2009;83(6):519-548.

27. Robins JM, Rotnitzky A, Zhao LP. Analysis of semiparametric regression models for repeated outcomes in the presence of missing data. J Am Stat Assoc 1995;90(429):106-121.

28. Romieu I, Castro-Giner F, Kunzli N, Sunyer J. Air pollution, oxidative stress and dietary supplementation: a review. Eur Respir
J 2008;31(1):179-197.

29. Monami M, Bardini G, Lamanna C, Pala L, Cresci B, Francesconi $P$, et al. Liver enzymes and risk of diabetes and cardiovascular disease: results of the Firenze Bagno a Ripoli (FIBAR) study. Metabolism 2008;57(3):387-392.

30. Strasak AM, Kelleher CC, Klenk J, Brant LJ, Ruttmann E, Rapp K, et al. Longitudinal change in serum gamma-glutamyltransferase and cardiovascular disease mortality: a prospective population-based study in 76,113 Austrian adults. Arterioscler Thromb Vasc Biol 2008;28(10):1857-1865.

31. Yun KE, Shin CY, Yoon YS, Park HS. Elevated alanine aminotransferase levels predict mortality from cardiovascular disease and diabetes in Koreans. Atherosclerosis 2009;205(2): 533-537.

32. Kim HC, Choi KS, Jang YH, Shin HW, Kim DJ. Normal serum aminotransferase levels and the metabolic syndrome: Korean National Health and Nutrition Examination Surveys. Yonsei Med J 2006;47(4):542-550.

33. Patel DA, Srinivasan SR, Xu JH, Chen W, Berenson GS. Persistent elevation of liver function enzymes within the reference range is associated with increased cardiovascular risk in young adults: the Bogalusa Heart Study. Metabolism 2007;56(6):792-798.

34. Doi Y, Kubo M, Yonemoto K, Ninomiya T, Iwase M, Tanizaki Y, et al. Liver enzymes as a predictor for incident diabetes in a Japanese population: the Hisayama study. Obesity (Silver Spring) 2007;15(7):1841-1850.

35. Monami M, Balzi D, Lamanna C, Melani C, Cocca C, Lotti E, et al. Prognostic value of serum liver enzymes levels in type $2 \mathrm{di}-$ abetic patients. Diabetes Metab Res Rev 2007;23(8):625-630.

36. Meng X, Wang C, Cao D, Wong CM, Kan H. Short-term effect of ambient air pollution on COPD mortality in four Chinese cities. Atmos Environ 2013;77:149-154.

37. Yu BP, Chung HY. Adaptive mechanisms to oxidative stress during aging. Mech Ageing Dev 2006;127(5):436-443.

38. Radak Z, Chung HY, Koltai E, Taylor AW, Goto S. Exercise, oxidative stress and hormesis. Ageing Res Rev 2008;7(1):34-42.

39. Bailey SM, Cunningham CC. Contribution of mitochondria to oxidative stress associated with alcoholic liver disease. Free Radic Biol Med 2002;32(1):11-16. 
Supplemental Table 1. Concentrations of the air pollutants and meteorological factors in Seongbuk-gu, Korea (2008-2010)

\begin{tabular}{|c|c|c|c|c|c|c|c|}
\hline & $\mathrm{PM}_{2.5}\left(\boldsymbol{\mu g} / \mathrm{m}^{3}\right)$ & $\mathrm{NO}_{2}(\mathrm{ppb})$ & $\mathrm{O}_{3}(\mathrm{ppb})$ & CO (10 ppm) & $\mathrm{SO}_{2}$ (ppb) & Temperature $\left({ }^{\circ} \mathrm{C}\right)$ & Dew point $\left({ }^{\circ} \mathrm{C}\right)$ \\
\hline \multicolumn{8}{|l|}{ Overall } \\
\hline Mean \pm SD & $23.2 \pm 11.5$ & $36.2 \pm 12.0$ & $47.6 \pm 27.4$ & $8.0 \pm 4.3$ & $3.9 \pm 2.1$ & $17.4 \pm 8.1$ & $6.4 \pm 9.5$ \\
\hline Median & 22.0 & 34.4 & 41.0 & 7.0 & 3.4 & 19.6 & 7.8 \\
\hline Range & $5.0,75.8$ & $9.8,77.3$ & $2.0,140.0$ & $3.0,27.0$ & $1.0,13.9$ & $-7.2,29.2$ & $-25.6,21.9$ \\
\hline IOR & 13.2 & 14.4 & 38.5 & 4.0 & 2.3 & 14.0 & 14.5 \\
\hline \multicolumn{8}{|l|}{ Spring ${ }^{1}$} \\
\hline Mean \pm SD & $23.0 \pm 10.3$ & $38.0 \pm 12.5$ & $41.7 \pm 18.7$ & $7.4 \pm 2.5$ & $3.9 \pm 1.8$ & $12.6 \pm 5.2$ & $0.8 \pm 7.5$ \\
\hline Median & 20.2 & 36.0 & 37.0 & 7.0 & 3.9 & 13.4 & 1.3 \\
\hline Range & $6.6,57.9$ & $12.8,71.6$ & $2.0,101.0$ & $3.0,13.0$ & $1.0,9.8$ & $1.8,23.9$ & $-18.5,16.1$ \\
\hline $\mathrm{IQR}$ & 11.1 & 20.1 & 23.0 & 5.0 & 2.4 & 8.9 & 9.1 \\
\hline \multicolumn{8}{|l|}{ Summer $^{2}$} \\
\hline Mean \pm SD & $19.9 \pm 11.4$ & $30.2 \pm 7.6$ & $62.9 \pm 30.9$ & $6.2 \pm 2.0$ & $2.9 \pm 0.9$ & $24.9 \pm 2.0$ & $14.4 \pm 5.2$ \\
\hline Median & 18.0 & 29.2 & 61.0 & 6.0 & 2.7 & 24.9 & 15.8 \\
\hline Range & $6.0,75.8$ & $16.6,48.8$ & $5.0,140.0$ & $3.0,15.0$ & $1.3,7.1$ & $19.1,29.2$ & $-0.7,21.9$ \\
\hline $\mathrm{IOR}$ & 15.5 & 10.0 & 42.0 & 2.0 & 1.1 & 2.7 & 6.5 \\
\hline \multicolumn{8}{|l|}{ Fall ${ }^{3}$} \\
\hline Mean \pm SD & $23.7 \pm 9.6$ & $36.7 \pm 10.5$ & $50.1 \pm 25.1$ & $8.0 \pm 3.6$ & $3.9 \pm 1.9$ & $19.8 \pm 6.0$ & $9.0 \pm 6.1$ \\
\hline Median & 24.0 & 36.1 & 51.0 & 7.0 & 3.6 & 22.4 & 9.1 \\
\hline Range & $5.0,54.0$ & $14.5,77.3$ & $8.0,97.0$ & $4.0,18.0$ & $1.4,10.2$ & $5.7,25.6$ & $-15.2,17.7$ \\
\hline $\mathrm{IQR}$ & 13.0 & 11.6 & 49.0 & 3.0 & 1.8 & 6.4 & 7.1 \\
\hline \multicolumn{8}{|l|}{ Winter $^{4}$} \\
\hline Mean \pm SD & $32.2 \pm 16.5$ & $45.5 \pm 16.7$ & $15.3 \pm 10.1$ & $15.2 \pm 7.8$ & $7.2 \pm 2.7$ & $3.5 \pm 5.4$ & $-7.3 \pm 8.6$ \\
\hline Median & 33.0 & 50.2 & 16.0 & 16.0 & 7.4 & 5.7 & -2.8 \\
\hline Range & $6.0,65.0$ & $9.8,65.9$ & $2.0,30.0$ & $3.0,27.0$ & $2.6,13.9$ & $-7.2,9.4$ & $-25.6,3.3$ \\
\hline $\mathrm{IQR}$ & 18.0 & 23.6 & 23.0 & 15.0 & 2.3 & 6.8 & 8.7 \\
\hline
\end{tabular}

$\mathrm{PM}_{2.5}$, particulate matter $\leq 2.5 \mu \mathrm{m}$; $\mathrm{NO}_{2}$, nitrogen dioxide; $\mathrm{O}_{3}$, ozone; $\mathrm{CO}$, carbon monoxide; $\mathrm{SO}_{2}$, sulfur dioxide; IQR, interquartile range; ppb, parts per billion; ppm, parts per million; SD, standard deviation.

${ }^{1}$ March, April, or May.

2June, July, or August.

${ }^{3}$ September, October, or November.

${ }^{4}$ December, January, or February. 
Journal of

Preventive Medicine

\& Public Health

Supplemental Table 2. Correlation between the concentrations of air pollutants on the day of the study visit

\begin{tabular}{lcccc}
\hline & $\mathbf{P M}_{\mathbf{2 . 5}}\left(\boldsymbol{\mu g} / \mathbf{m}^{\mathbf{3}}\right)$ & $\mathbf{N O}_{2}(\mathbf{p p b})$ & $\mathbf{O}_{3}(\mathbf{p p b})$ & $\mathbf{C O}(\mathbf{1 0} \mathbf{p p m})$ \\
\hline $\mathrm{NO}_{2}(\mathrm{ppb})$ & 0.6590 & & & \\
$p$-value & $<0.001$ & & & \\
$\mathrm{O}_{3}$ (ppb) & 0.0753 & -0.1512 & & \\
$p$-value & $<0.05$ & $<0.001$ & & \\
$\mathrm{CO}(10 \mathrm{ppm})$ & 0.6541 & 0.6993 & -0.2994 & \\
$p$-value & $<0.001$ & $<0.001$ & $<0.001$ & \\
$\mathrm{SO}_{2}$ (ppb) & 0.5777 & 0.6164 & -0.2267 & 0.7237 \\
$p$-value & $<0.001$ & $<0.001$ & $<0.001$ & $<0.001$ \\
\hline
\end{tabular}

$\mathrm{PM}_{2.5}$, particulate matter $\leq 2.5 \mu \mathrm{m} ; \mathrm{NO}_{2}$, nitrogen dioxide; $\mathrm{O}_{3}$, ozone; $\mathrm{CO}$, carbon monoxide; $\mathrm{SO}_{2}$, sulfur dioxide; ppb, parts per billion; ppm, parts per million.

${ }^{1}$ Pearson correlation coefficients. 
Supplemental Table 3. Percent change in liver enzyme levels with an interquartile range increase in the concentrations of $\mathrm{PM}_{2.5}$, $\mathrm{NO}_{2}$, and $\mathrm{O}_{3}$, stratified by physical activity and alcohol drinking ${ }^{1}$

\begin{tabular}{|c|c|c|c|c|c|c|c|c|c|c|c|}
\hline & \multirow[b]{2}{*}{ Pollutant } & \multirow[b]{2}{*}{$\mathbf{n}$} & \multicolumn{3}{|c|}{ AST } & \multicolumn{3}{|c|}{ ALT } & \multicolumn{3}{|c|}{$\gamma$-GTP } \\
\hline & & & Estimate & $95 \%$ CI & $\begin{array}{c}p \text { for } \\
\text { interaction }\end{array}$ & Estimate & $95 \%$ CI & $\begin{array}{c}p \text { for } \\
\text { interaction }\end{array}$ & Estimate & $95 \% \mathrm{Cl}$ & $\begin{array}{c}p \text { for } \\
\text { interaction }\end{array}$ \\
\hline \multicolumn{12}{|c|}{ Physical activity } \\
\hline \multirow[t]{2}{*}{$\geq 1 /$ wk } & $\mathrm{PM}_{2.5}$ & 330 & 0.6 & $-2.1,3.4$ & 0.04 & 3 & $-0.1,6.6$ & 0.50 & 5.8 & $1.1,10.5$ & 0.48 \\
\hline & $\mathrm{NO}_{2}$ & 327 & 3.1 & $-0.1,6.3$ & 0.86 & 3.9 & $0.1,7.7$ & 0.49 & -0.3 & $-5.7,5.1$ & 0.20 \\
\hline \multirow{2}{*}{$<1 /$ wk } & $\mathrm{NO}_{2}$ & 197 & 4.1 & $-0.02,8.2$ & & 4.1 & $-1.3,9.4$ & & -4.7 & $-10.9,1.5$ & \\
\hline & $\mathrm{O}_{3}$ & 199 & 5.3 & $0.2,10.4$ & & 6 & $-0.2,12.2$ & & 6.4 & $-1.3,14.1$ & \\
\hline \multicolumn{12}{|c|}{ Alcohol drinking } \\
\hline \multirow[t]{2}{*}{ No } & $\mathrm{PM}_{2.5}$ & 405 & 2.5 & $0.1,4.8$ & 0.53 & 3.7 & $0.5,6.9$ & 0.50 & 2.8 & $-0.1,6.4$ & 0.008 \\
\hline & $\mathrm{NO}_{2}$ & 402 & 5 & $2.1,7.8$ & 0.51 & 5.6 & $2.2,9.1$ & 0.22 & -1.6 & $-5.9,2.7$ & 0.78 \\
\hline$<1 /$ wk & $\mathrm{O}_{3}$ & 55 & 4.1 & $-5.9,14.2$ & & 10.4 & $-3.1,23.9$ & & 10.1 & $-6.3,26.3$ & \\
\hline \multirow[t]{3}{*}{$\geq 1 /$ wk } & $\mathrm{PM}_{2.5}$ & 64 & 4.2 & $-2.0,10.4$ & & 1 & $-11.5,13.4$ & & 20 & $6.3,33.8$ & \\
\hline & $\mathrm{NO}_{2}$ & 64 & -0.9 & $-8.4,6.5$ & & 4.8 & $-6.4,16.1$ & & -10.5 & $-26.5,5.5$ & \\
\hline & $\mathrm{O}_{3}$ & 65 & -7.3 & $-17.9,3.2$ & & 17.6 & $4.9,30.2$ & & 18.8 & $0.6,37.0$ & \\
\hline
\end{tabular}

AST, aspartate aminotransferase; ALT, alanine aminotransferase; $\gamma$-GTP, $\gamma$-glutamyltranspeptidase; $\mathrm{Cl}$, confidence interval; $\mathrm{PM}_{2.5}$, particulate matter $\leq 2.5 \mu$ m; $\mathrm{NO}_{2}$, nitrogen dioxide; $\mathrm{O}_{3}$, ozone.

${ }^{1}$ Changes in liver enzyme levels by an interquartile range increase in the concentrations of air pollutants were estimated using a linear mixed model after adjusting for age, sex, smoking status, mean temperature, dew point, season, body mass index, alcohol consumption, and amount of exercise. 
Supplemental Table 4. Associations between air pollutant and liver enzyme levels in multi-day lag models

\begin{tabular}{|c|c|c|c|c|c|c|c|c|c|c|}
\hline & \multirow{2}{*}{ Lag day } & \multicolumn{3}{|c|}{ AST } & \multicolumn{3}{|c|}{ ALT } & \multicolumn{3}{|c|}{$\gamma$-GTP } \\
\hline & & Estimate & $95 \% \mathrm{CI}$ & $p$-value & Estimate & $95 \% \mathrm{Cl}$ & $p$-value & Estimate & $95 \% \mathrm{CI}$ & $p$-value \\
\hline \multirow[t]{6}{*}{$\mathrm{PM}_{2.5}$} & 1 & 0.0255 & $0.0007,0.0503$ & 0.04 & -0.0005 & $-0.0315,0.0305$ & 0.97 & 0.0085 & $-0.0331,0.0502$ & 0.69 \\
\hline & 2 & 0.0375 & $0.0096,0.0654$ & 0.008 & 0.015 & $-0.0199,0.0499$ & 0.40 & 0.0115 & $-0.0354,0.0584$ & 0.63 \\
\hline & 3 & 0.0467 & $0.0174,0.0760$ & 0.002 & 0.0226 & $-0.0142,0.0594$ & 0.23 & 0.0348 & $-0.0147,0.0842$ & 0.17 \\
\hline & 4 & 0.0448 & $0.0157,0.0740$ & 0.003 & 0.0208 & $-0.0157,0.0573$ & 0.26 & 0.0447 & $-0.0043,0.0937$ & 0.07 \\
\hline & 5 & 0.04 & $0.0106,0.0695$ & 0.008 & 0.0175 & $-0.0195,0.0544$ & 0.35 & 0.0418 & $-0.0078,0.0914$ & 0.10 \\
\hline & 6 & 0.0391 & $0.0082,0.0700$ & 0.01 & 0.0129 & $-0.0259,0.0516$ & 0.51 & 0.0298 & $-0.0222,0.0819$ & 0.26 \\
\hline \multirow[t]{6}{*}{$\mathrm{NO}_{2}$} & 1 & 0.0275 & $-0.0001,0.0550$ & 0.05 & -0.0102 & $-0.0445,0.0240$ & 0.56 & -0.0164 & $-0.0620,0.0293$ & 0.48 \\
\hline & 2 & 0.0443 & $0.0123,0.0763$ & 0.007 & 0.0116 & $-0.0283,0.0515$ & 0.57 & -0.0083 & $-0.0614,0.0449$ & 0.76 \\
\hline & 3 & 0.0557 & $0.0196,0.0919$ & 0.002 & 0.0264 & $-0.0186,0.0714$ & 0.25 & 0.0055 & $-0.0545,0.0656$ & 0.86 \\
\hline & 4 & 0.0532 & $0.0146,0.0918$ & 0.007 & 0.0239 & $-0.0243,0.0720$ & 0.33 & 0.0085 & $-0.0557,0.0727$ & 0.79 \\
\hline & 5 & 0.0498 & $0.0085,0.0911$ & 0.02 & 0.0081 & $-0.0433,0.0595$ & 0.76 & 0.0024 & $-0.0662,0.0709$ & 0.94 \\
\hline & 6 & 0.0541 & $0.0108,0.0974$ & 0.01 & 0.0016 & $-0.0523,0.0556$ & 0.95 & -0.0012 & $-0.0731,0.0707$ & 0.97 \\
\hline \multirow[t]{6}{*}{$\mathrm{O}_{3}$} & 1 & 0.0099 & $-0.0362,0.056$ & 0.67 & 0.0039 & $-0.0539,0.0616$ & 0.89 & 0.0048 & $-0.0729,0.0824$ & 0.90 \\
\hline & 2 & 0.0231 & $-0.0286,0.0749$ & 0.38 & 0.0174 & $-0.0473,0.0822$ & 0.60 & 0.0037 & $-0.0834,0.0908$ & 0.93 \\
\hline & 3 & 0.0281 & $-0.0254,0.0816$ & 0.30 & 0.0293 & $-0.0377,0.0962$ & 0.39 & 0.0381 & $-0.0520,0.1282$ & 0.41 \\
\hline & 4 & 0.0342 & $-0.0201,0.0885$ & 0.22 & 0.0368 & $-0.0311,0.1048$ & 0.29 & 0.0698 & $-0.0216,0.1612$ & 0.13 \\
\hline & 5 & 0.0334 & $-0.0221,0.0911$ & 0.23 & 0.0504 & $-0.0205,0.1212$ & 0.16 & 0.0813 & $-0.0140,0.1765$ & 0.09 \\
\hline & 6 & 0.0323 & $-0.0286,0.0931$ & 0.30 & 0.0574 & $-0.0186,0.1335$ & 0.14 & 0.1003 & $-0.0020,0.2026$ & 0.05 \\
\hline \multirow[t]{6}{*}{$\mathrm{CO}$} & 1 & -0.0001 & $-0.0237,0.0235$ & 0.99 & -0.0114 & $-0.0410,0.0181$ & 0.45 & -0.0037 & $-0.0435,0.0361$ & 0.85 \\
\hline & 2 & 0.0055 & $-0.0223,0.0333$ & 0.70 & 0.0039 & $-0.0309,0.0387$ & 0.82 & -0.0101 & $-0.0569,0.0368$ & 0.67 \\
\hline & 3 & 0.0085 & $-0.0240,0.0409$ & 0.61 & 0.0128 & $-0.0278,0.0534$ & 0.54 & -0.0092 & $-0.0638,0.0455$ & 0.74 \\
\hline & 4 & 0.0067 & $-0.0281,0.0414$ & 0.71 & 0.0028 & $-0.0406,0.0463$ & 0.90 & -0.0166 & $-0.0750,0.0419$ & 0.58 \\
\hline & 5 & 0.0048 & $-0.0323,0.0419$ & 0.80 & -0.0040 & $-0.0504,0.0425$ & 0.87 & -0.0198 & $-0.0823,0.0427$ & 0.53 \\
\hline & 6 & 0.0089 & $-0.0305,0.0483$ & 0.66 & -0.0028 & $-0.0521,0.0465$ & 0.91 & -0.0213 & $-0.0876,0.0450$ & 0.53 \\
\hline \multirow[t]{6}{*}{$\mathrm{SO}_{2}$} & 1 & 0.0107 & $-0.0173,0.0387$ & 0.45 & -0.0103 & $-0.0451,0.0244$ & 0.56 & -0.0185 & $-0.0648,0.0278$ & 0.43 \\
\hline & 2 & 0.0153 & $-0.0153,0.0484$ & 0.33 & -0.0037 & $-0.0417,0.0343$ & 0.85 & -0.0298 & $-0.0805,0.0208$ & 0.25 \\
\hline & 3 & 0.021 & $-0.0116,0.0535$ & 0.21 & -0.0032 & $-0.0437,0.0373$ & 0.88 & -0.0244 & $-0.0783,0.0286$ & 0.37 \\
\hline & 4 & 0.0244 & $-0.0096,0.0584$ & 0.16 & 0.0028 & $-0.0394,0.0451$ & 0.89 & -0.0138 & $-0.0701,0.0425$ & 0.63 \\
\hline & 5 & 0.0224 & $-0.0137,0.0586$ & 0.22 & -0.0037 & $-0.0486,0.0412$ & 0.87 & -0.0086 & $-0.0685,0.0512$ & 0.78 \\
\hline & 6 & 0.0217 & $-0.0163,0.0598$ & 0.26 & -0.0098 & $-0.0571,0.0375$ & 0.68 & -0.0090 & $-0.0720,0.0540$ & 0.78 \\
\hline
\end{tabular}

AST, aspartate aminotransferase; ALT, alanine aminotransferase; $\gamma$-GTP, $\gamma$-glutamyltranspeptidase; $\mathrm{Cl}$, confidence interval; $\mathrm{PM}_{2.5}$, particulate matter $\leq 2.5 \mu$ m; $\mathrm{NO}_{2}$, nitrogen dioxide; $\mathrm{O}_{3}$, ozone; $\mathrm{CO}$, carbon monoxide; $\mathrm{SO}_{2}$, sulfur dioxide.

${ }^{1}$ Changes in liver enzyme levels by an interquartile range increase in the concentrations of air pollutants were estimated using a linear mixed model after adjusting for age, sex, smoking status, mean temperature, dew point, season, body mass index, alcohol consumption, and amount of exercise. 
Supplemental Table 5. Associations between air pollutant and liver enzyme levels in unconstrained distributed lag models

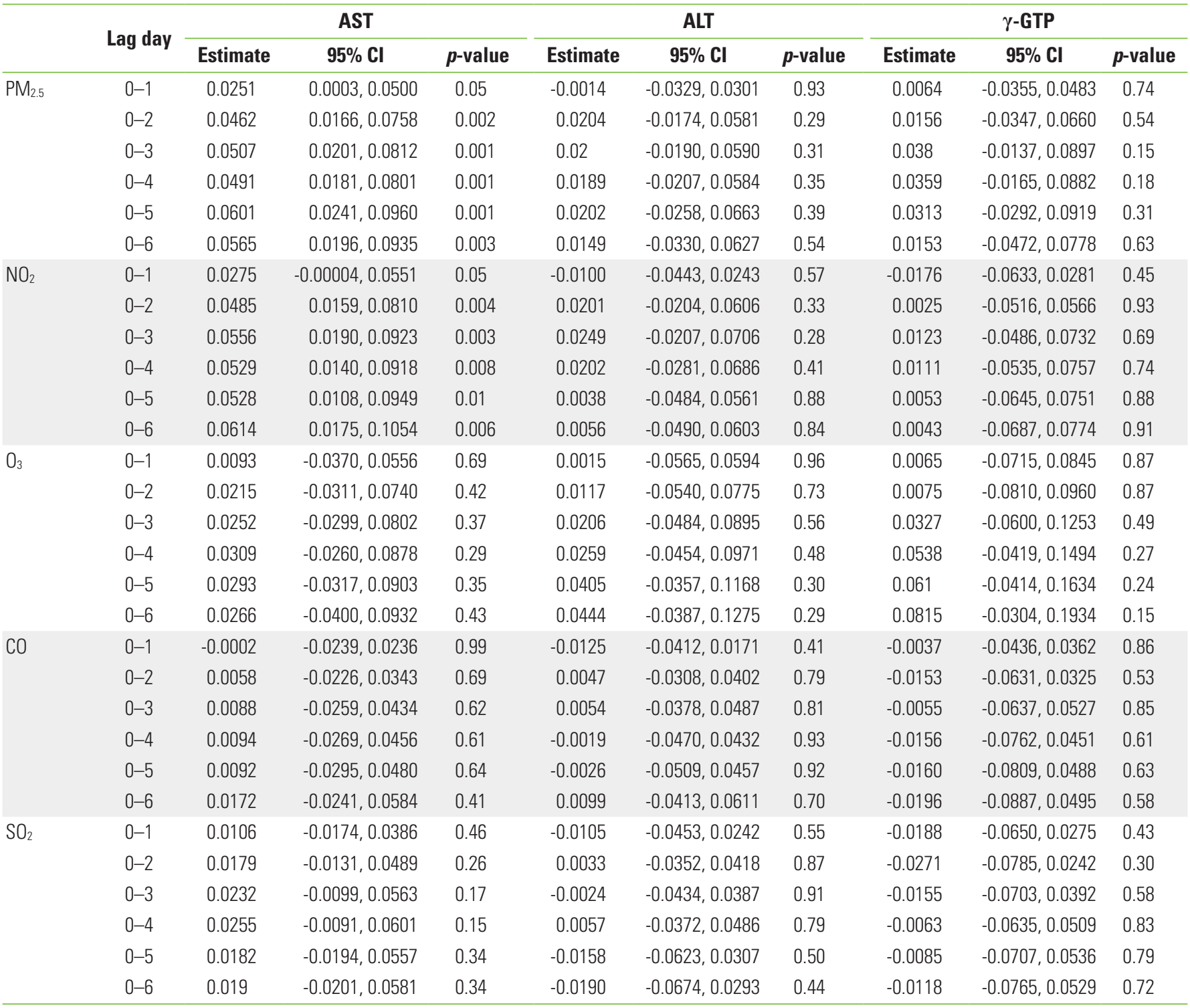

AST, aspartate aminotransferase; ALT, alanine aminotransferase; $\gamma$-GTP, $\gamma$-glutamyltranspeptidase; $\mathrm{Cl}$ : confidence interval; $\mathrm{PM}_{2.5}$, particulate matter $\leq 2.5 \mu$ m; $\mathrm{NO}_{2}$, nitrogen dioxide; $\mathrm{O}_{3}$, ozone; $\mathrm{CO}$, carbon monoxide; $\mathrm{SO}_{2}$, sulfur dioxide.

${ }^{1}$ Changes in liver enzyme levels by an interquartile range increase of air pollutants were estimated using a linear mixed model after adjusting for age, sex, smoking status, mean temperature, dew point, season, body mass index, alcohol consumption, and amount of exercise. 


\section{Journal of}

Supplemental Table 6. Percent change in liver enzyme levels with an interquartile increase in the concentrations of air pollutants in single-day lag models ${ }^{1}$ after inverse probability weighting for follow-up visits.

\begin{tabular}{|c|c|c|c|c|c|c|c|c|c|c|}
\hline & \multirow{2}{*}{ IOR } & \multicolumn{3}{|c|}{ AST } & \multicolumn{3}{|c|}{ ALT } & \multicolumn{3}{|c|}{$\gamma$-GTP } \\
\hline & & Estimate & $95 \% \mathrm{CI}$ & $p$-value & Estimate & $95 \% \mathrm{Cl}$ & $p$-value & Estimate & $95 \%$ Cl & $p$-value \\
\hline $\mathrm{PM}_{2.5}$ & $13.2 \mu \mathrm{g} / \mathrm{m}^{3}$ & 3.7 & $1.5,5.8$ & $<0.001$ & 3.6 & $0.6,6.6$ & 0.02 & 6.4 & $2.8,10.1$ & $<0.001$ \\
\hline $\mathrm{NO}_{2}$ & 14.4 ppb & 4.2 & $1.7,6.8$ & $<0.001$ & 4.1 & $1.1,7.3$ & 0.007 & -2.3 & $-6.2,1.7$ & 0.25 \\
\hline $\mathrm{O}_{3}$ & $38.5 \mathrm{ppb}$ & 2.9 & $-0.3,6.3$ & 0.08 & 2.4 & $-1.2,6.1$ & 0.19 & 5.8 & $0.9,10.9$ & 0.02 \\
\hline $\mathrm{CO}$ & $4.0 \mathrm{ppm}$ & 1.3 & $-1.0,3.6$ & 0.28 & 2.7 & $-0.1,5.7$ & 0.06 & 0.3 & $-3.7,4.4$ & 0.88 \\
\hline $\mathrm{SO}_{2}$ & $2.3 \mathrm{ppb}$ & 2.6 & $0.2,5.1$ & 0.04 & -1.6 & $-4.7,1.5$ & 0.31 & -2.7 & $-7.2,1.5$ & 0.20 \\
\hline
\end{tabular}

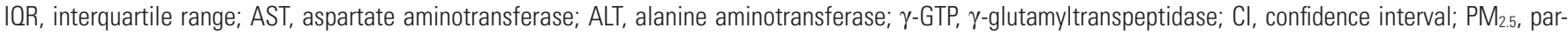
ticulate matter $\leq 2.5 \mu \mathrm{m} ; \mathrm{NO}_{2}$, nitrogen dioxide; $\mathrm{O}_{3}$, ozone; $\mathrm{CO}$, carbon monoxide; $\mathrm{SO}_{2}$, sulfur dioxide; ppb, parts per billion; ppm, parts per million.

${ }^{1}$ Associations with $\mathrm{AST}$ are shown for $\mathrm{NO}_{2}, \mathrm{O}_{3}$, and $\mathrm{CO}$ on lag day 2 and for $\mathrm{PM}_{2.5}$ and $\mathrm{SO}_{2}$ on lag day 3 . Associations with $\mathrm{ALT}_{\text {are }}$ shown for $\mathrm{SO}_{2}$ on lag day 1 ; for $\mathrm{PM}_{2.5}, \mathrm{NO}_{2}$, and $\mathrm{CO}$ on lag day 2; and for $\mathrm{O}_{3}$ on lag day 5. Associations with $\gamma$-GTP are shown for $\mathrm{NO}_{2}$ and $\mathrm{SO}_{2}$ on day 1 , for $\mathrm{PM}_{2.5}$ on lag day 3 , and for $\mathrm{O}_{3}$ and $\mathrm{CO}$ on lag day 4. All models were adjusted for age, sex, smoking status, mean temperature, dew point, season, body mass index, alcohol consumption, and amount of exercise. 


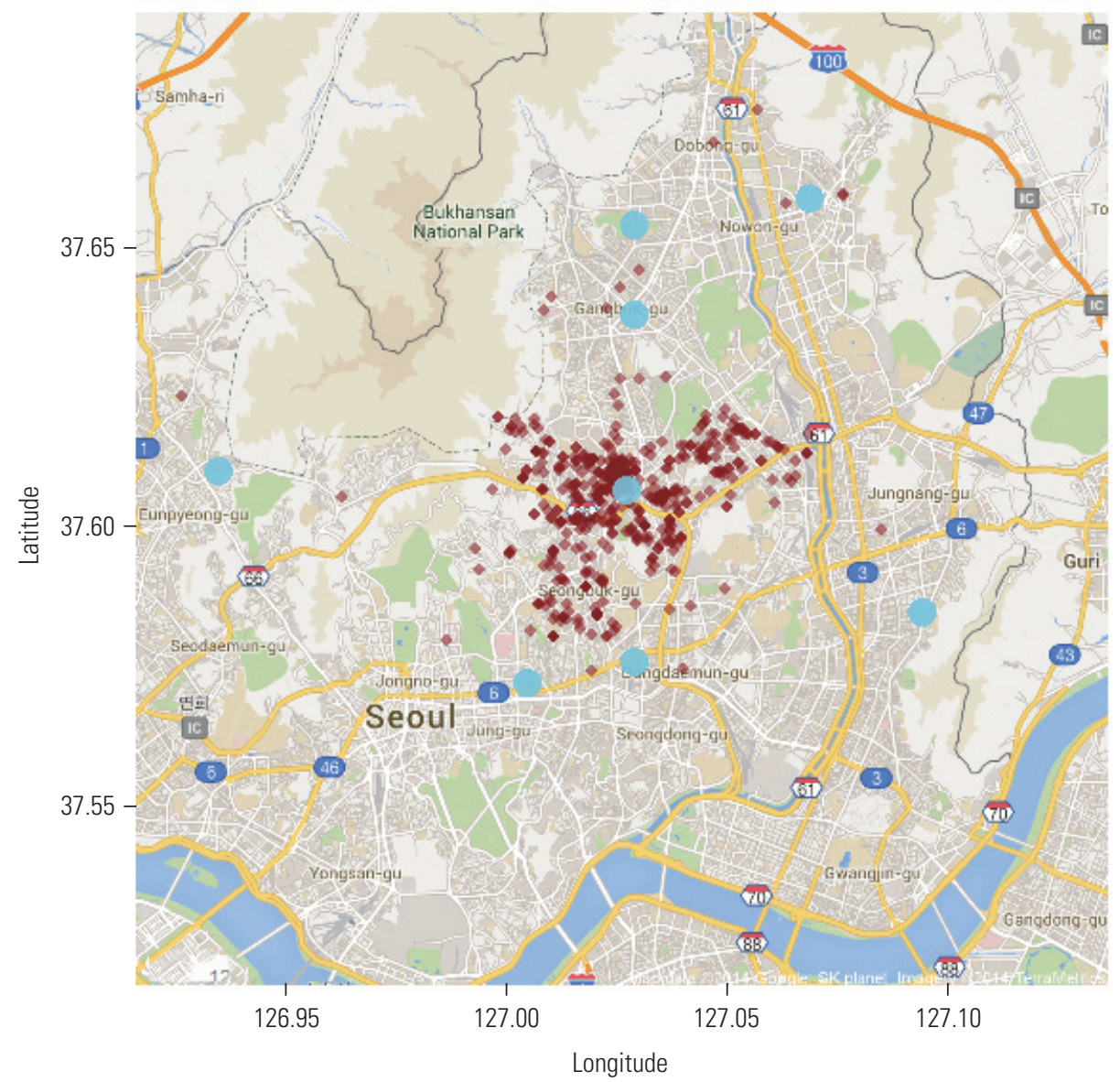

Supplemental Figure 1. Map indicating the monitoring sites and address of the participants. Blue circle, monitoring sites; Red dot, address of the participant. 

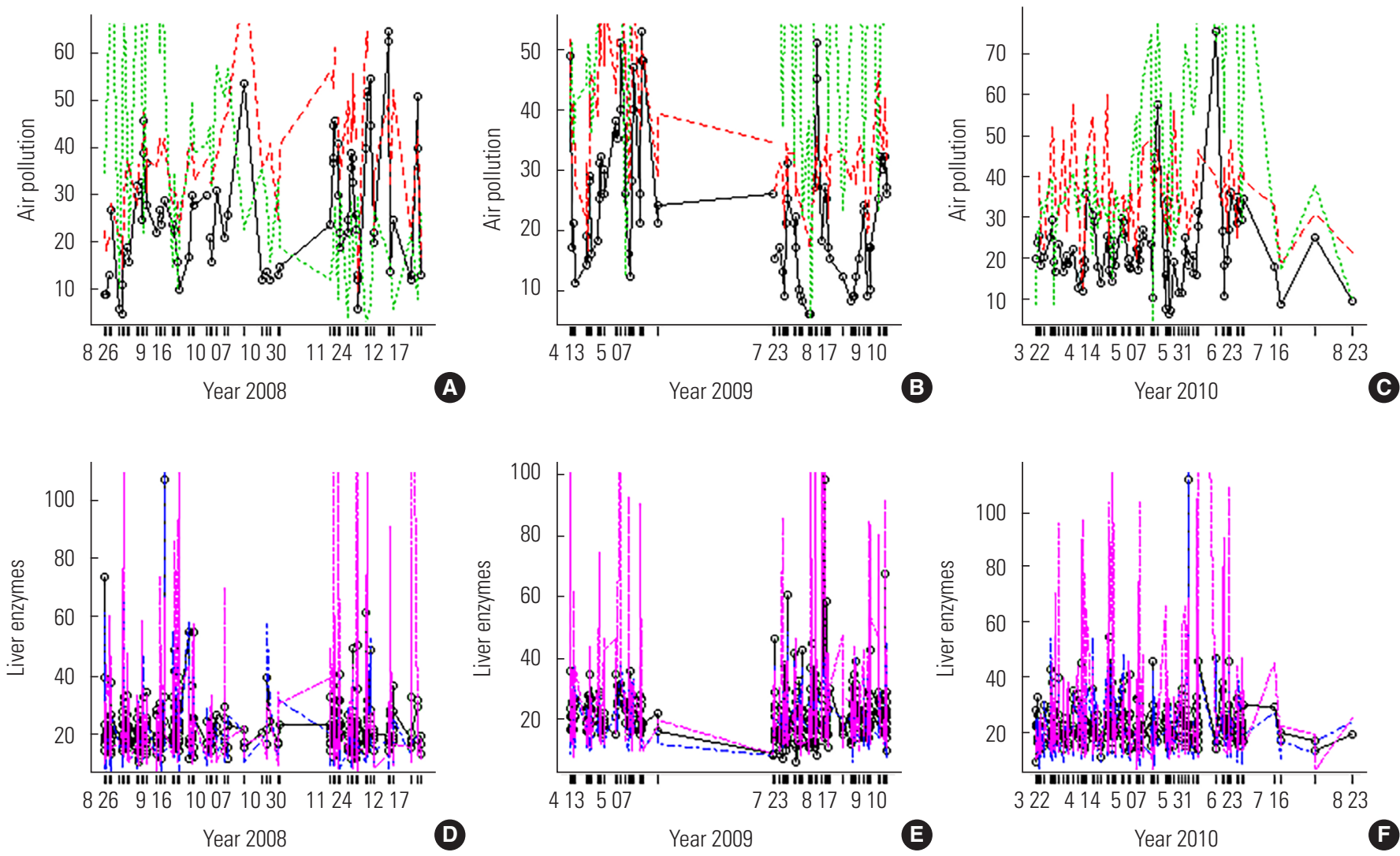

Supplemental Figure 2. Daily distribution of particulate matter $\leq 2.5 \mu \mathrm{m}\left(\mathrm{PM}_{2.5}\right)$, nitrogen dioxide $\left(\mathrm{NO}_{2}\right)$, ozone $\left(\mathrm{O}_{3}\right) \mathrm{concentra-}$ tions $(A-C)$, and alanine aminotransferase (AST), alanine aminotransferase (ALT), and $\gamma$-glutamyltranspeptidase ( $\gamma$-GTP) levels (D-F) during the study period, 2008-2010. PM 2.5, black; $\mathrm{NO}_{2}$, red; $\mathrm{O}_{3}$, green; AST, black; ALT, blue; -GTP, purple. 

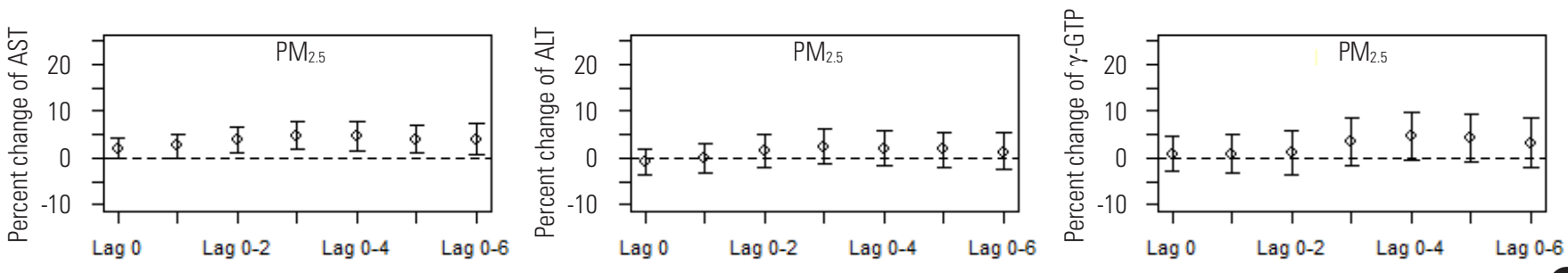

A
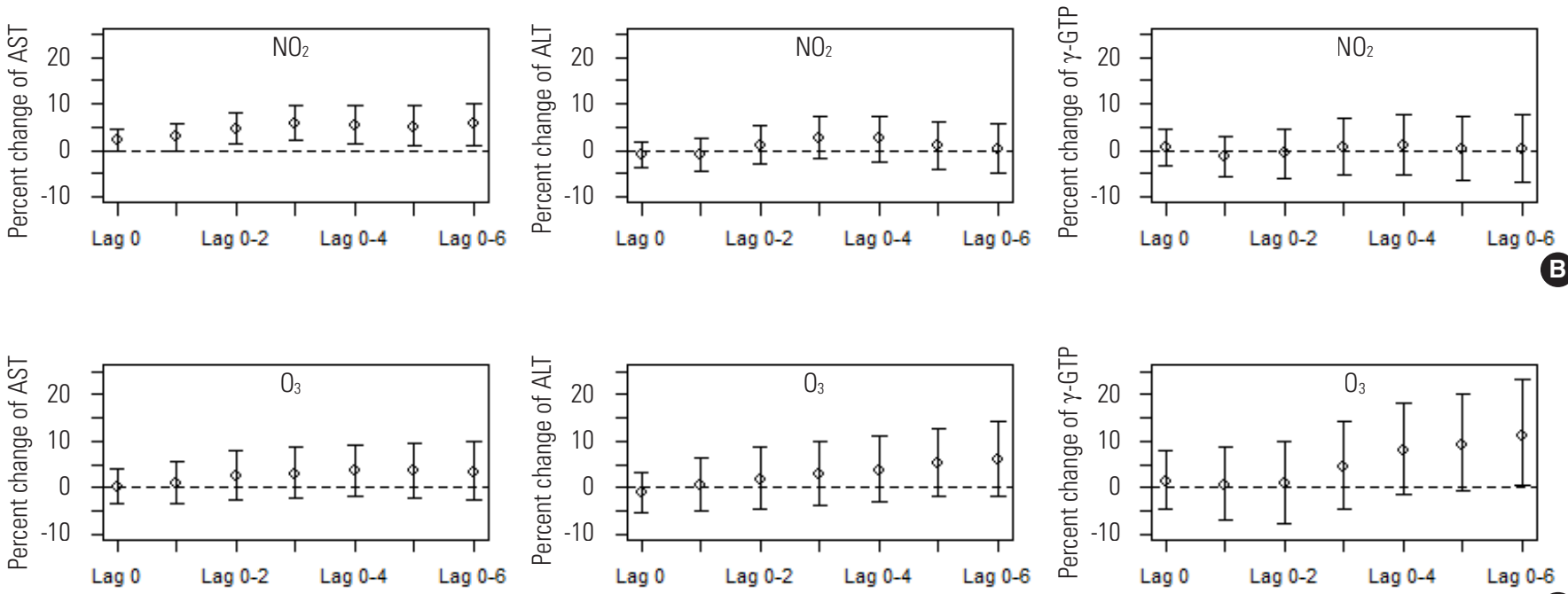

Supplemental Figure 3. Associations of particulate matter $\leq 2.5 \mu \mathrm{m}\left(\mathrm{PM}_{2.5}\right)$, nitrogen dioxide $\left(\mathrm{NO}_{2}\right)$, and ozone $\left(\mathrm{O}_{3}\right)$ concentrations with alanine aminotransferase (AST), alanine aminotransferase (ALT), and $\gamma$-glutamyltranspeptidase ( $\gamma$-GTP) levels in multiday lag models. The percent changes in the concentrations of AST, ALT, and $\mathrm{Y}$-GTP by interquartile range increases of (A) PM 2.5 ,

(B) $\mathrm{NO}_{2}$, and (C) $\mathrm{O}_{3}$ were estimated by linear mixed models adjusted for age, sex, smoking status, mean temperature, dew point, season, body mass index, alcohol consumption, and amount of exercise. For details, see also Supplemental Table 4. 

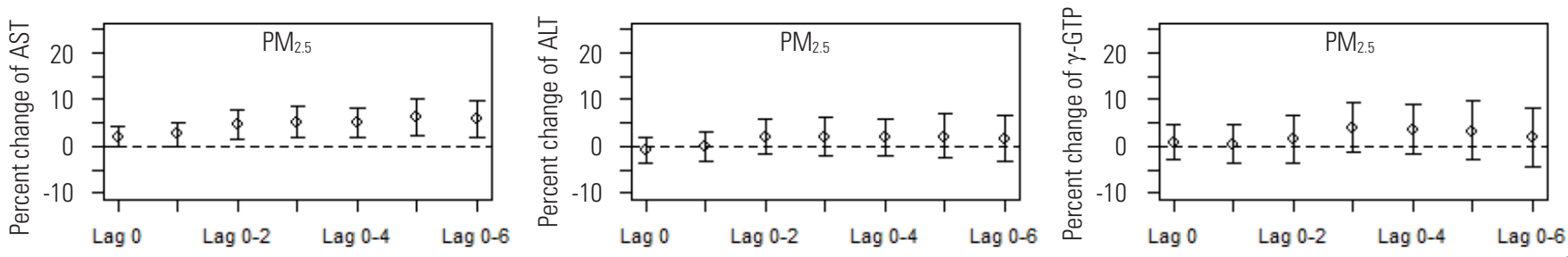

A
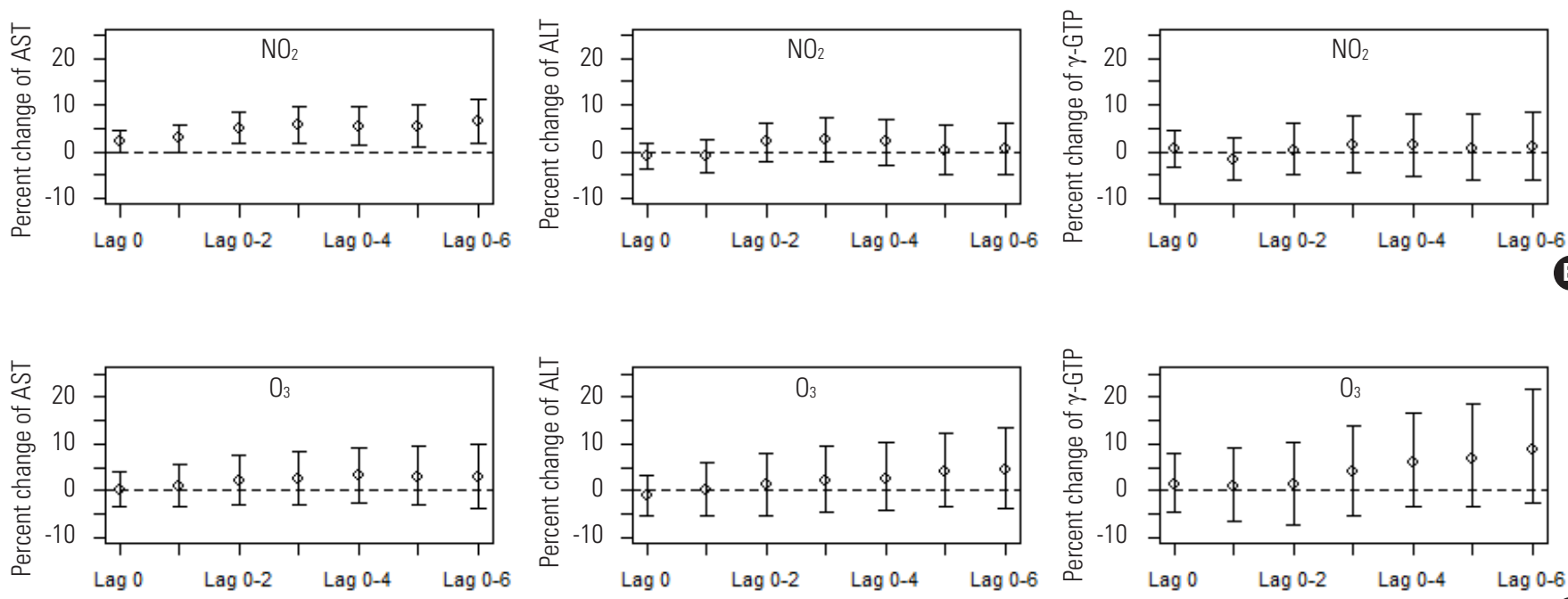

C

Supplemental Figure 4. Associations of particulate matter $\leq 2.5 \mu \mathrm{m}\left(\mathrm{PM}_{2.5}\right)$, nitrogen dioxide $\left(\mathrm{NO}_{2}\right)$, and ozone $\left(\mathrm{O}_{3}\right)$ with alanine aminotransferase (AST), alanine aminotransferase (ALT), and $\gamma$-glutamyltranspeptidase ( $\gamma$-GTP) in unconstrained distributed lag models. Percent changes in the levels of AST, ALT, and $\gamma$-GTP by interquartile range increase of (A) $\mathrm{PM}_{2.5}$, (B) $\mathrm{NO}_{2}$, and (C) $\mathrm{O}_{3}$ concentrations were estimated by linear mixed models adjusted for age, sex, smoking status, mean temperature, dew point, season, body mass index, alcohol consumption, and amount of exercise. For details, see also Supplemental Table 5. 